\title{
Preparing to Evacuate your Home in Case of an Emergency ${ }^{1}$
}

Elizabeth B. Bolton ${ }^{2}$

During these times of potential terrorist attacks, it is important to plan for the worst and hope that it never happens. For example, you and your family may be asked to leave your home due to some emergency situation in your community. Your local emergency officials will not ask you to leave your home or location unless there is a valid reason. Do not try and second-guess the validity of their request. Do as they say immediately. Most of the time these requests and related information will come through radio broadcasts or the local TV station. Different warning methods may be used such as a siren or telephone calls.

Stay tuned and follow the directions and the evacuation routes recommended by the emergency officials. The most important thing to keep in mind is to have a plan for a possible evacuation. Be prepared to evacuate and keep the following suggestions in mind.

\section{Know the route and follow directions.}

Keep a map on hand that will enable you to take a route that may be unfamiliar to you. Be prepared to use routes specified by the emergency officials. Do not use any road or shortcut that they do not recommend. Some areas familiar to you may no longer be accessible or they may be dangerous for reasons unknown to you.

\section{Local Authorities will Tell You What to Do.}

Stay in touch with local authorities. They are in touch with the state or federal authorities and will know which route to take and what local conditions might be. If you follow their instructions, you are more likely to arrive in a safe location and to be able to communicate with your family members or friends.

\section{Keep your vehicle's tank/s filled.}

Stations may not be open during times of emergency. During power outages, fuel pumps at gas stations may not work.

\section{One vehicle per Household}

Plan to take one vehicle per household. This will keep family members together and reduce the number of cars on your particular evacuation route.

\section{Power Lines}

Do not go near power lines especially if they are broken or down.

1. This document is FCS9194, one of a series of the Department of Family, Youth and Community Sciences, Florida Cooperative Extension Service, IFAS, University of Florida, Gainesville FL 32611: First published: May 2003. Reviewed by Nayda I. Torres, Ph.D. Department of Family, Youth and Community Sciences. Please visit the EDIS Web site at http://edis.ifas.ufl.edu

2. Elizabeth B. Bolton, PH.D., professor, Department of Family, Youth and Community Sciences, University of Florida, Gainesville FL 32611. 


\section{Clothing}

Wear clothing that protects you as much as possible. Even though it not cold or hot during a particular time of year, wear clothing that protects you. Wear long sleeves and long pants. Wear sturdy shoes that would be suitable for walking which you may, or may not, have to do. Take along a hat that can be used to shelter you from the sun.

\section{Disaster Kit}

Take your disaster kit with the supplies you will need. The kit will include items such as a battery powered radio, extra batteries, food, water, and clothing. Plan for no less than three days.

\section{Phone}

Bring your cellular phone.

\section{Prepare your home before leaving it.}

- $\quad$ Lock all doors and windows.

- Turn off electric and water. You should know how to use the tools needed to do this. These typically include an adjustable pipe and crescent wrench.

- If you have food in a home freezer, your local officials will advise you as to whether or not to turn off the electricity.

- Leave your natural gas on unless you are instructed to turn it off. You may need gas for heating or cooking and only a professional can turn it on once it has been turned off. In times of emergency, it may take days or weeks to get a professional to your home to turn on your gas once it has been turned off.

\section{Family Communications}

If you have time, call your family and friends. In any event, leave a note as to the route you are taking and your destination. Put your emergency communications plan into effect as follows.

- Choose an out of town contact your family or household will call or e-mail to check on each other should a disaster occur. Your selected contact should live far enough away that they would be unlikely to be directly affected by the same event and they should know they are the chosen contact.

- $\quad$ Make sure every household member has that contact's, and each other's, e-mail addresses and telephone numbers (home, work, pager and cell). Leave these contact numbers at your children's school, if you have children, and at your workplace.

- $\quad$ Your family should know that if telephones are not working, they need to be patient and try again later or try e-mail. Many people flood the telephone lines when emergencies happen but e-mail can sometimes get through when calls don't.

\section{Emergency Shelters}

Know in advance where the emergency shelters are located. If there is more than one in your vicinity, know all the locations. The steps you should take in preparing for shelter depends on the type of emergency situation. For example, during a tornado you should go to an underground room if it is available. During a chemical release, you should seek shelter in a room above ground.

\section{Shelter in Place}

If your emergency officials tell you to "shelter in place," this means that you should remain inside your home or office and protect yourself there.

- $\quad$ Close and lock all windows and exterior doors.

- $\quad$ Turn off all fans, heating and air conditioning systems.

- $\quad$ Close the fireplace damper. 
- $\quad$ Get your disaster kit and make sure your radio is working.

- Go to an interior room without windows that is above ground level. In the case of a chemical threat, an above-ground lkocation is preferable because some chemicals are heavier than air, and may seep into basements even if the windows are closed. Using duct tape, seal all cracks around the door and any vents into the room.

- $\quad$ Keep listening to your radio or television until you are told all is safe or that you are to evacuate. The length of your stay can range from a few hours to two weeks. During this time your should maintain a 24 hour communications and safety watch. Take turns with family in listening for radio broadcasts.

- Watch for fires.

- $\quad$ Assemble an emergency toilet, if necessary. Use a garbage container, pail or bucket with a snug-fitting cover. If the container is small, use a larger container with a cover for waste disposal. Line both containers with plastic bags. After each use, pour or sprinkle a small amount of regular household disinfectant, such as chlorine bleach, into the container to reduce odor or germs.

\section{Predetermined meeting place}

Have a predetermined destination for meeting your family in the event you are separated from them. This will save time and anxiety as well as minimize the confusion if you are told to evacuate. Have some prior arrangements with friends or family who may provide temporary shelter in case of emergency. If you have pets, make plans for where they will be sheltered.

\section{Children at School}

Have a plan for who is to pick up the children from school or how they will be taken care of and by whom if they are not at home.

\section{Animals and pets}

Have a plan for caring for animals in the event of an emergency evacuation. 